\title{
Genesis dan Klasifikasi Tanah Ultisol di Lahan Kering Kabupaten Aceh Besar
}

\author{
(Genesis and Classification of Ultisol soils in the dry \\ land of the district of Aceh Besar) \\ Raziah $^{1}$, Sufardi ${ }^{1}$, Teti Arabia ${ }^{1 *}$ \\ ${ }^{1}$ Program Studi Ilmu Tanah, Fakultas Pertanian, Universitas Syiah Kuala \\ Corresponding author: tetiarabia@unsyiah.ac.id
}

\begin{abstract}
Abstrak. Penelitian ini bertujuan untuk menentukan proses genesis dan melakukan klasifikasi tanah Ultisol di Desa Jalin Kecamatan Jantho Kabupaten Aceh Besar, dikarenakan belum adanya data dan informasi mengenai klasifikasi dan proses genesis yang terjadi pada tanah Ultisol yang terbentuk di desa Jalin Kecamatan Jantho Penelitian dilakukan dengan membuka profil tanah dan mengamati faktor morfologi dan mengambil sampel tanah untuk keperluan analisis laboratorium. Berdasarkan hasil penelitian tanah Ultisol di Desa Jalin Kecamatan Jantho terbentuk di atas formasi batuan Tuktp (Tertary III upper Keutapang) dengan jenis batuan Jenis batuan yang terdapat yaitu batu sedimen, batu pasir, batu gampingan, batu lanau dan batu gamping, yang terbentuk pada zaman kenozoikum periode pertengahan meiosen-pliosen, berumur antara 23,030 - 5,332 juta tahun yang lalu. Memiliki topografi landai $>8 \%$, dan tipe iklim C (agak basah), Adapun proses-proses genesis yang terjadi yaitu dekomposisi, braunifikasi, eluviasi, iluviasi dan hardening. Klasifikasi tanah Ultisol memiliki epipedon okhrik di karenakan horizon permukaan yang tipis karena yaitu $10 \mathrm{~cm}$, walaupun kandungan bahan organik adalah 1,89\%, warna tanah dengan nilai value dalam keadaan lembab sebesar 5, sedangkan nilai chroma dalam keadaan lembab sebesar 6. dan endopedon argilik karena memiliki memiliki horizon iluviasi apabila liat $15-40 \%$, maka harus mengandung liat 1,2 kali lebih banyak dari horizon eluviasi. Kandungan liat eluviasi pada lokasi penelitian yaitu $11 \%$ dan horizon liat horizon iluviasi sebesar 23 dan 29\%, kategori tingkat sub ordo: Aquult, kategori great group: Kandiaquult, kategori subgrup: Typic Kandiaquult, dan famili Typic Kandiaquult, berdebu halus, campuran, isohipertermik.
\end{abstract}

Kata Kunci: Ultisol, genesis tanah, klasifikasi tanah

\begin{abstract}
This study aims to determine the process of genesis and to classify Ultisol soil in Jalin Village, Jantho Subdistrict, Aceh Besar Regency, due to the absence of data and information regarding the classification and process of genesis that occurs in Ultisol soil formed in Jalin village, Jantho Subdistrict. The research was conducted by opening the soil profile and observing morphological factors and taking soil samples for laboratory analysis. Based on the results of Ultisol soil research in Jalin Village, Jantho Subdistrict, it was formed on the Tuktp (Tertary III upper Keutapang) rock formation with rock types. Types of rocks contained were sedimentary rocks, sandstone, limestone, siltstone and limestone formed in the Kenozoic era. the mid-meiocene-pliocene period, aged between 23,030 - 5,332 million years ago. It has a sloping topography> 8\%, and climate type C (slightly wet). The genesis processes that occur are decomposition, braunification, eluviation, iluviation and hardening. Ultisol soil classification has an ochric epipedon because of the thin surface horizon because it is 10 $\mathrm{cm}$, although the organic matter content is $1.89 \%$, the color of the soil with a value in the humid state of 5 , while the chroma value in the humid state of 6 . and argillic endopedon because it has an iluviation horizon when clay is $15-40 \%$, it must contain 1.2 times more clay than the eluviation horizon. The eluviation clay content at the study site was $11 \%$ and the horizon of the illuviation horizon was 23 and 29\%, the sub-order level category: Aquult, great group category: Kandiaquult, subgroup category: Typic Kandiaquult, and Typic Kandiaquult family, fine dust, mixture, isohipertermic.
\end{abstract}

Keywords: Ultisols, soil genesis, soil classification

\section{PENDAHULUAN}

Kabupaten Aceh Besar dengan ibu kota Kota Jantho, terdiri dari 23 kecamatan secara geografis terletak pada posisi $5^{\circ}, 2^{\prime}-5^{\circ}, 8^{\prime} \mathrm{LU}$ dan $95^{\circ} 80^{\prime}-95^{\circ}, 88^{\prime} \mathrm{BT}$, berada pada ketinggian tempat mulai dari 12 sampai 400 meter di atas permukaan laut. Menurut Pusat Data Informasi 
Pertanian (2013) dari 1.140.548,54 ha total luas lahan pertanian yang ada di Provinsi Aceh sekitar 89.227,34 ha merupakan lahan kering yang terdiri dari: lahan non irigasi, lahan tegal/kebun, ladang dan lahan tidur atau terlantar (Martunis et al., 2016). Luas lahan kering Kabupaten Aceh Besar yaitu 89.134,34 ha yang terbentuk atas beberapa jenis tanah seperti Podsolik, Kambisol, Inceptisol, Aluvial, Litosol, Andisol, dan Renzina (Sufardi et al., 2017).

Meskipun lahan kering di Aceh umumnya dan khususnya Aceh Besar sangat luas tetapi optimalisasi penggunaan nya sangatlah kurang, hal tersebut di sebabkan karena kurangnya data dan informasi tentang kualitas tanah di Kabupaten Aceh Besar. Untuk mengetahui kualitas tanah maka perlu di lakukan pengklasifikasian serta mengamati prosesproses pedogenesis yang terjadi pada tanah tersebut supaya dapat diketahui sifat-sifatnya.

Sifat-sifat tanah yang terbentuk sangat dipengaruhi oleh bahan induk karena selama terjadi proses pelapukan dan pedogenesis, beberapa sifat asli dari bahan induk hilang (Buol et al., 1997). Penelitian ini diharapkan dapat memberikan tambahan informasi tentang prosesproses pembentukan dan klasifikasi tanah di Indonesia umunya dan khususnya di Kabupaten Aceh Besar.

\section{METODE PENELITIAN}

Proses pengkajian genesis dan klasifikasi jenis tanah Ultisol Jantho/Jalin $05^{0} 16^{\prime} 58,41^{\prime}$ LU, 95037'51,82" BT $156 \mathrm{~m}$ dpl. di lahan kering Kabupaten Aceh Besar, dengan menggunakan metode survei deskriptif kuantitatif yaitu melalui observasi lapangan dan analisis laboratorium. Dilakukan pembukaan profil tanah untuk mengamati sifat morfologi tanah di lapangan kemudian dilakukan pengambilan sampel tanah untuk keperluan analisis laboratorium. Analisi laboratorium dilakukan di Penelitian laboratorium dengan menganalisis contoh tanah dilaksanakan di Laboratorium Penelitian Tanah dan Tanaman dan Laboratorium Penelitian Fisika Tanah Fakultas Pertanian, serta Laboratorium Fisika Material Fakultas MIPA Universitas Syiah Kuala Darussalam, Banda Aceh.

Bahan yang di gunakan untuk penelitian ini adalah: Peta administrasi, Peta jenis tanah Peta geologi, Peta penggunaan lahan, Peta lereng, Peta pengambilan titik sampel Kabupaten Aceh Besar. Selain itu sampel tanah dan bahan-bahan larutan seperti $\mathrm{H}_{2} \mathrm{O}_{2} 10 \%$ dan larutan $\mathrm{HCl} 1 \mathrm{~N}$ untuk menganalisis sifat-sifat tanah di lapangan, dan bahan kimia untuk analisis laboratorium. Alat yang digunakan dalam penelitian ini adalah: GPS (global positioning system), Abney level, kantong plastik, karet, kartu deskripsi profil tanah, buku Munsell Soil Colour Chart, meteran, kamera digital, cangkul, sekop, bor tanah, pisau tanah, alat tulis, dan alat pendukung lainnya di laboratorium.

Sampel tanah yang telah diambil dari lapangan sebelum dianalisis terlebih dahulu dikering-anginkan selama 1 minggu, kemudian ditumbuk dan diayak menggunakan ayakan 2,0 untuk analisis tekstur tanah setelah di dapat fraksi liat lalu digunakan untuk anlisis mineral tanah dengan menggunakan XRD, dan menggunakan ayakan $0,5 \mathrm{~mm}$ untuk analisis sifat-sifat kimia tanah seperti $\mathrm{pH}, \mathrm{C}$-organik, kation basa dapat ditukar (Ca-dd, $\mathrm{Mg}$-dd, $\mathrm{K}$-dd, dan $\mathrm{Na}$ dd), kapasitas tukar kation (KTK), kejenuhan basa (KB), serta kemasaman tanah dapat ditukar (Al-dd dan H-dd). Metode dan prosedur analisis tanah berpedoman pada prosedur yang dikeluarkan oleh Pusat Penelitian Tanah Bogor (2009).

Selanjutnya dilakukan pengklasifikasian tanah berdasarkan Taksonomi Tanah (Soil Survey Staff, 2014). dari mulai kategori ordo, kemudian subordo, great group, subgrup, 
sampai famili, setelah didapat hasil analisis laboratorium maka tahap selanjutnya baru ditentukan proses-proses genesis berdasarkan lima faktor pembentuk tanah.

\section{HASIL DAN PEMBAHASAN}

\section{Karakteristik Morfologi Tanah}

Hasil pengamatan tanah Ultisol horizon Ap dengan ketebalan $(10 \mathrm{~cm})$ pada kedalaman $(0-10 \mathrm{~cm})$ merupakan horizon permukaan tanah yang mengalami pengolahan tanah, karena pedon yang diamati di lapangan terlihat adanya pengolohan tanah. Horizon AB dengan ketebalan $(12 \mathrm{~cm})$ pada kedalaman $(10-27 \mathrm{~cm})$, merupakan horizon peralihan A ke B tetapi lebih mirip B. Horizon BA dengan ketebalan $(52 \mathrm{~cm})$ pada kedalaman $(45-97 \mathrm{~cm})$, adalah horizon peralihan A ke B tetapi lebih mirip dengan horizon B. Horizon Bt merupakan horizon $B$ yang mempunyai akumulasi liat tinggi dan juga menunjukkan adanya perkembangan warna atau struktur. Horizon Bt1 dengan ketebalan $(52 \mathrm{~cm})$ pada kedalaman $(45-97 \mathrm{~cm})$. Horizon $\mathrm{Bt} 2$ dengan ketebalan $(28 \mathrm{~cm})$ pada kedalaman $(97-125 \mathrm{~cm})$.

Hal ini menunjukkan kriteria termasuk kedalam kategori horizon penciri argilik dengan kandungan liat filosilikat secara jelas lebih tinggi pada horizon Bt dan memiliki tekstur tanah halus disebabkan banyaknya akumulasi liat. Kandungan liat eluviasi Dan horizon iluviasi, tingginya liat pada horizon $\mathrm{Bt}$ disebabkan banyak terjadi pencucian tanah pada lapisan atas dan mengendap pada horizon bawah. Batas horizon yang diamati di lapangan adalah beralih baur dan beralih angsur kemudian beralih baur kembali. Dengan batas topografi berombak/bergelombang dan lurus.

Warna tanah adalah petunjuk untuk beberapa sifat tanah, karena warna dipengaruhi oleh beberapa faktor yang terdapat dalam tanah. Penyebab perbedaan warna permukaan tanah umumnya oleh kandungan bahan organik. Semakin tinggi kandungan bahan organik, warna tanah semakain gelap (Hardjowigeno, 2010).

Warna tanah Ultisol yang diamati di lapangan dapat dilihat pada Tabel 2. Warna tanah pada horizon Ap berkisar coklat terang $(7,5 \mathrm{YR} 5 / 6)$, pada horizon AB coklat kekuningkuningan (10YR 5/6), pada horizon BA berkisar coklat kekuning-kuningan terang (10YR 6/6), pada horizon Bt1 dan Bt2 berkisar abu-abu terang (10YR $7 / 1$ ), Dan karatan Fe mulai terdapat dari horizon $\mathrm{AB}-\mathrm{Bt} 2$.

Warna tanah pada masing-masing horizon menunjukkan adanya perubahan warna dari warna cokelat sampai kepada warna kekuningan terang. Perubahan warna yang terjadi di karenakan horizon atas banyak mengantung bahan organik semakin kebawah kandungan bahan organik semakin berkurang, warna tanah pada horizon bawah di pengaruhi oleh bentuk dan banyak nya kandungan Fe yang didapat.

Struktur tanah merupakan sifat fisik tanah yang menggambarkan susunan keruangan partikel-partikel tanah yang bergabung antara satu dengan yang lain membentuk agregat. Dalam tinjauan morfologi, struktur tanah diartikan sebagai susunan partikel-partikel primer menjadi satu kelompok partikel (cluster) yang disebut agregat, yang dapat dipisah-pisahkan kembali serta mempunyai sifat yang berbeda dari sekumpulan partikel primer yang tidak teragregasi (Handayani dan Bambang, 2002).

Ultisol dijumpai bentuk struktur tanah pada horizon Ap yaitu tiang ukurannya besar dan tingkat perkembangan sedang. Horizon $\mathrm{AB}$ bentuk struktur tiang ukurannya besar dan tingkat 
perkembangan kuat. Horizon BA sampai Bt2 memiliki bentuk struktur gumpal bersudut dengan ukuran besar dan tingkat perkembangannya sedang.

Tabel 1. Hasil indentifikasi karakteriktik morfologi tanah Ultisol di lahan kering Kabupaten Aceh Besar

\begin{tabular}{|c|c|c|c|c|c|c|c|c|c|c|c|c|c|c|}
\hline \multirow{3}{*}{$\begin{array}{l}\text { Horison/ } \\
\text { Kedalama } \\
\mathrm{n} \\
(\mathrm{cm})\end{array}$} & \multirow{3}{*}{$\begin{array}{c}\mathrm{Ba} \\
- \\
\text { tas } \\
\text { ho } \\
\text { r. }\end{array}$} & \multirow{3}{*}{$\begin{array}{l}\text { Ba- } \\
\text { tas } \\
\text { top. }\end{array}$} & \multirow{3}{*}{$\begin{array}{l}\text { Warna } \\
\text { Matriks } \\
\text { Tanah }\end{array}$} & \multicolumn{6}{|c|}{ Karatan Tanah } & \multirow{3}{*}{$\begin{array}{l}\text { Struktur } \\
\text { Tanah }\end{array}$} & \multicolumn{2}{|c|}{ Konsistensi } & \multirow{3}{*}{$\mathrm{P}$} & \multirow{3}{*}{$\begin{array}{c}\text { Akar } \\
\text { tana- } \\
\text { man }\end{array}$} \\
\hline & & & & \multicolumn{2}{|c|}{$\begin{array}{c}\text { Warna Karatan } \\
\text { Tanah } \\
\end{array}$} & \multirow{2}{*}{$\mathrm{J}$} & \multirow{2}{*}{$\mathrm{U}$} & \multirow{2}{*}{$\begin{array}{l}B \\
d\end{array}$} & \multirow{2}{*}{$\mathrm{Bt}$} & & \multirow{2}{*}{$\begin{array}{l}\text { Lem } \\
\text {-bab }\end{array}$} & \multirow{2}{*}{ Ba-sah } & & \\
\hline & & & & $\mathrm{Fe}$ & $\mathrm{Mn}$ & & & & & & & & & \\
\hline Ap/0-10 & $\mathrm{a}$ & $\mathrm{O}$ & $7,5 \mathrm{YR}^{5} / 6$ & - & - & - & - & - & - & $\mathrm{sd}, \mathrm{bs}, \mathrm{ti}$ & $\mathrm{Tg}$ & Alk & $\mathrm{pl}$ & $\mathrm{h}$ \\
\hline $\mathrm{AB} / 10-27$ & a & $\mathrm{O}$ & $10 \mathrm{YR} 5 / 6$ & $5 \mathrm{YR}^{4} / 6$ & - & sd & $\mathrm{Sd}$ & $\mathrm{d}$ & Ap & $\mathrm{ku}, \mathrm{bs}, \mathrm{ti}$ & $\mathrm{Tg}$ & Alk & $\mathrm{pl}$ & $\mathrm{h}$ \\
\hline $\mathrm{BA} / 27-45$ & $\mathrm{~b}$ & $\mathrm{O}$ & $10 \mathrm{YR} 6 / 6$ & $\begin{array}{l}2,5 \mathrm{YR} \\
4 / 8\end{array}$ & - & bi & $\mathrm{Sd}$ & $\mathrm{d}$ & Ap & sd,bs, gs & $\mathrm{Tg}$ & Alk & $\mathrm{pl}$ & $\mathrm{h}$ \\
\hline Bt1/45-97 & $\mathrm{b}$ & $\mathrm{O}$ & $10 \mathrm{YR}^{7} / 1$ & $\begin{array}{l}2,5 \mathrm{YR} \\
4 / 8\end{array}$ & - & ba & $\mathrm{Sd}$ & d & Ap & sd, bs,gs & $\mathrm{Tg}$ & Lk & $\mathrm{pl}$ & $\mathrm{h}$ \\
\hline $\begin{array}{l}\mathrm{Bt} 2 / 97- \\
124\end{array}$ & $\mathrm{~b}$ & $\mathrm{O}$ & $10 \mathrm{YR}^{7} / 1$ & $5 \mathrm{YR}^{4} / 6$ & - & ba & $\mathrm{Sd}$ & $\mathrm{d}$ & Ap & $\begin{array}{l}\text { sd, bs, } \\
\text { gs }\end{array}$ & $\mathrm{Tg}$ & Alk & $\mathrm{pl}$ & $\mathrm{h}$ \\
\hline
\end{tabular}

Keterangan: $7,5 \mathrm{YR} 5 \%=$ coklat terang, 10YR $5 / 6=$ coklat kekuning-kuningan, $10 \mathrm{YR} \%$ = coklat kekuning-kuningan terang, $10 \mathrm{YR} 7 / 1=$ abu-abu terang $5 \mathrm{YR}^{4} / 4=$ coklat kemerahan kusam, $2,5 \mathrm{YR} 5 / 8=$ coklat kemerahan terang, Batas hor (Batas horizon), Batas top (Batas topografi), O (ombak), L (lurus), W (Warna), J (Jumlah), U (Ukuran), Bd (Bandingan); Bt (Bentuk); T (Tekstur); S (Struktur); K (Kelembaban); L (Lembab); B (Basah); P (Plastisitas); pl (plastis); BO (Bahan organik), a (angsur); b (baur); 1 (lurus); bi (biasa), k (kasar), d (jelas), bs (bintik berganda), pi (pipe), Li-L (Liat berlempung), Li (Liat), P-Kr (Pasir berkerikil), lm (lemah), h (halus), r (remah), sd (dedang), g (gumpal), bs (besar), tg (teguh), pl (plastis), alk (agak lekat), lk (lekat).

Penetapan konsistensi tanah di lapangan dalam keadaan tanah basah dan lembab. Konsistensi pada kondisi basah merupakan penetapan konsistensi tanah pada kondisi air tanah pada kapasitas lapang (field capacity). Konsistensi pada kondisi lembab merupakan penetapan konsistensi tanah pada kondisi kadar air tanah sekitar kapasitas lapang.

Pada lokasi penelitian Ultisol horizon Ap sampai Bt2 memiliki berkonsistensi agak lekat (basah) dan teguh (lembab), kecuali horizon Bt1 berkonsistensi lekat (basah) dan teguh (lembab) (Tabel 1). Hal tersebut diakibatkan karena pada horizon Bt1 dan Bt2 merupakan horizon timbunan liat sehingga berkonsistensi lekat dan teguh ketika kering.

\section{Karakteristik Fisika Tanah}

Tabel 2. Hasil analisis karakteristik fisika tanah di lokasi penelitian

\begin{tabular}{|c|c|c|c|c|c|c|c|c|c|c|}
\hline \multirow[b]{2}{*}{$\begin{array}{l}\text { Jenis } \\
\text { Tanah }\end{array}$} & \multirow[b]{2}{*}{$\begin{array}{c}\text { Horison/ } \\
\text { Kedalaman } \\
\text { (cm) }\end{array}$} & \multirow[b]{2}{*}{$\begin{array}{c}\text { Bulk } \\
\text { Density } \\
\left(\mathrm{g} \mathrm{cm}^{3}\right)\end{array}$} & \multicolumn{2}{|c|}{ Permeabilitas } & \multirow{2}{*}{ Porositas } & \multirow{2}{*}{$\begin{array}{c}\mathrm{pF} \\
2.45 \\
(\%)\end{array}$} & \multicolumn{3}{|c|}{ Tekstur tanah } & \multirow[b]{2}{*}{$\begin{array}{c}\text { Kelas } \\
\text { Tekstur }\end{array}$} \\
\hline & & & $\begin{array}{c}\text { Nilai } \\
\text { cm.jam }_{1}^{-}\end{array}$ & Kriteria & & & Pasir & $\begin{array}{c}\text { Debu } \\
--\%- \\
--\end{array}$ & Liat & \\
\hline \multirow[t]{5}{*}{ Ultisol } & Ap/0-10 & - & - & - & - & - & 29 & 60 & 11 & LD \\
\hline & $\mathrm{AB} / 10-27$ & - & - & - & - & - & 31 & 40 & 29 & $\mathrm{LLi}$ \\
\hline & BA/27-45 & 1,30 & 0,18 & Lambat & 36,30 & 33,6 & 4 & 90 & 5 & $\mathrm{D}$ \\
\hline & Bt1/45-97 & 1,55 & 0,15 & Lambat & 38,29 & 26,11 & 13 & 64 & 23 & LD \\
\hline & Bt2/97-124 & 1,49 & 0,27 & Lambat & 38,90 & 28,40 & 2 & 69 & 29 & LD \\
\hline
\end{tabular}

Keterangan: $\mathrm{L}=$ lempung, $\mathrm{Li}=$ liat, dan $\mathrm{D}=$ debu 
Tanah Ultisol memiliki kadar air tanah pada horizon BA 33,6\%, pada horizon Bt1 26,11\% dan pada horizon Bt2 28,40\%. Kadar air tanah kapasitas lapang tergolong tinggi, dikarenakan tanah Ultisol mempunyai tekstur tanah yang tergolong halus.

Bobot isi tanah adalah kerapatan tanah yang di kemukakan dalam dua kriteria berikut: (1) kerapatan partikel (bobot partikel $=\mathrm{BP}$ ) merupakan bobot massa partikel padat per satuan volume tanah, setiap tanah biasanya mempunyai kerapatan partikel, dan (2) kerapatan massa (bobot isi = BI) yaitu bobot massa tanah kondisi lapang yang dikering-ovenkan per satuan volume (Hanafiah, 2005).

Bobot isi Ultisol masing-masing horizon dari BA sampai Bt2 yaitu $1,30 \mathrm{~g} \mathrm{~cm}^{-3}, 1,55 \mathrm{~g}$ $\mathrm{cm}^{-3}$, dan $1,49 \mathrm{~g} \mathrm{~cm}^{-3}$. Bobot isi Ultisol sangat tinggi di karenakan adnya horizon argilik yang mempunyai kandungan liat yang tinggi. Kandungan liat yang tinggi membuat bobot isi tanah jadi tinggi dikarenakan bobot isi tanah kedap air laju infiltrasi rendah dan aliran permukaan serta erosi meningkat (Dudal dan Supraptoharjo, 1957).

Permeabilitas merupakan cepat lambatnya air merembes kedalam tanah baik melalui pori-pori makro maupun pori-pori mikro baik kearah horizontal maupun vertikal. Laju permeabilitas pada Ultisol horizon BA sampai dengan horizon Bt2 berkriteria lambat dengan masing-masing nilai $0,15 \mathrm{~cm} \mathrm{jam}^{-1}, 0,18 \mathrm{~cm} \mathrm{jam}^{-1}$ dan $0,27 \mathrm{~cm} \mathrm{jam}^{-1}$. Koefesian permeabilitas terutama tergantung pada ukuran rata-rata porositas yang dipengaruhi oleh distribusi ukuran partikel, bentuk partikel dan struktur tanah. secara garis besar, semakin kecil ukuran partikel, semakin kecil pula ukuran porositas dan semakin rendah koefesien permeabilitas nya. Laju permeabilitas lokasi penelitian tergolong kedalam kriteria lambat, permeabilitas yang lambat atau kecil berkaitan dengan porositas tanah yang kurang baik disebabkan drainase yang buruk.

Porositas atau ruang pori total adalah ruang volume seluruh pori-pori makro dan mikro dalam tanah yang dinyatakan dalam persentase volum tanah di lapangan. Porositas tanah adalah kemampuan tanah dalam menyerap air berkaitan dengan tingkat kepadatan tanah. semakin padat tanah berarti semakin sulit untuk menyerap air, maka porositas tanah semakin kecil, sebaliknya semakin mudah tanah menyerap air maka tanah tersebut mempunyai porositas yang besar.

Tanah Ultisol memiliki porositas pada horizon BA 36,30\%, pada horizon Bt1 38,29\%, dan pada horizon Bt2 38,90\%. Tergolong kurang baik dikarenakan tanah ultisol memiliki bobot isi yang tinggi dikarenkan tingginya kandungan liat.

Tekstur tanah menunjukkan perbandingan relatif tiga golongan besar partikel tanah dalam suatu massa tanah yaitu pertikel pasir, debu dan liat (Hakim et al., 1986). Tekstur tanah pada lokasi penelitian dapat dilihat pada (Tabel 2). Tanah Ultisol bertekstur lempung berdebu, lempung berliat dan debu, termasuk kelas besar butir berdebu halus. Liat tertinggi terdapat pada horizon Bt1-Bt2 hal ini disebabkan adanya endapan liat yang berbeda sehingga memenuhi kriteria horizon penciri argilik.

\section{Karakteristik Kimia Tanah}

Reaksi tanah adalah salah satu dari beberapa indikator kesuburan tanah, sama dengan keracunan tanah. Level optimum $\mathrm{pH}$ tanah untuk aplikasi penggunaan lahan berkisar antara 5 - 7,5. Tanah dengan $\mathrm{pH}$ rendah (asam) dan $\mathrm{pH}$ tinggi (alkalis) membatasi pertumbuhan tanaman. Efek pH tanah pada umumnya tidak langsung. Di dalam kultur larutan umumnya tanaman budidaya yang dipelajari pertumbuhannya baik/sehat pada level $\mathrm{pH}$ 4,8 atau lebih (Bunting, 1981). Reaksi pH tanah menunjukkan banyaknya konsentrasi ion hidrogen (di dalam tanah). Makin tinggi kadar ion di dalam tanah, semakin masam tanah tersebut. Bila 
kandungan $\mathrm{H}$ sama dengan maka tanah bereaksi netral yaitu mempunyai $\mathrm{pH}=7$ (Hardjowigeno, 2010).

Tanah Ultisol memiliki reaksi tanah pada horizon Ap 5,26, horizon AB 5,97, horizon BA 6,34, horizon Bt1 6,41 dan horizon Bt2 6,60. Dari setiap horizon terjadi kenaikan pH yang signifikan dan reaksi $\mathrm{pH}$ mendekati netral kecuali pada kedua horizon atas. Kejenuhan basa pada horizon Ap 24,15\%, horizon AB 22,74\%, horizon BA 15,29\%, horizon Bt1 28,78, dan menurun drastis pada horizon $\mathrm{Bt} 24,41 \%$. Kejenuhan basa di bawah $50 \%$ menunjukan kedalam epipedon penciri okhrik (penciri jenis tanah Ultisol)

Kandungan bahan organik pada masing-masing horizon merupakan petunjuk besarnya akumulasi bahan organik dalam keadaan lingkungan yang berbeda. Penciri penting untuk tanah-tanah yang proses pembentukannya banyak dipengaruhi bahan organik (Hardjowigeno, 2003).

Tanah Ultisol pada lokasi penelitian memiliki kandungan bahan organik pada horizon Ap adalah 1,89\%, hoizon AB 0,33\%, horizon BA 0,34\%, horizon Bt1 0,17\%, dan horizon Bt2 $0,13 \%$.

Nilai asam-asam dd kation $\mathrm{H}$ di lokasi penelitian pada Ultisol kation $\mathrm{H}$ pada horizon $\mathrm{Ap}$ sampai Bt2 bernilai 0,96 cmol. $\mathrm{kg}^{-1}, 0,40 \mathrm{cmol} \cdot \mathrm{kg}^{-1}, 0,32 \mathrm{cmol} \cdot \mathrm{kg}^{-1}, 0,24 \mathrm{cmol} \cdot \mathrm{kg}^{-1}$, dan 0,24 cmol. $\mathrm{kg}^{-1}$. Nilai kation $\mathrm{Al}$ hanya terukur di horizon Ap sedangkan horizon lain tidak terukur.

Hakim et al. (1986) menyatakan dalam kedaan yang sangat masam, Al menjadi sangan larut yang dijumpai dalam bentuk $\mathrm{Al}^{3+}$ dan hidroksida Al. Kedua ion $\mathrm{Al}$ tersebut lebih mudah terjerap pada koloid liat dari pada ion $\mathrm{H}$. Oleh karena itu $\mathrm{Al}$ berada dalam larutan tanah mudah terhidrolisis, maka $\mathrm{Al}$ merupakan penyebab kemasaman atau penyumbang ion $\mathrm{H}$. Ion $\mathrm{H}$ yang dibebaskan secara demikian akan memberikan nilai $\mathrm{pH}$ rendah bagi larutan tanah dan merupakan sumber utama ion $\mathrm{H}$ dalam sebagian tanah masam.

Nilai EA liat pada Ultisol horizon di bawah kedalaman Bt2 yaitu $1,00 \mathrm{cmol}^{\mathrm{kg}}{ }^{-1}$ dan tergolong sangat rendah. Pengukuran EA hanya dilakukan pada Ultisol saja dikarenakan pedon 3 menurut pengamatan lapangan termasuk kedalam tanah Ultisol, salah satu syarat tanah Ultisol memiliki kejenuhan basa < dari 30\% pada kedalaman dibawah $130 \mathrm{~cm}$. Nilai EA digunakan untuk menghitung KTK jumlah kation dan KB jumlah kation. KB jumlah kation pada lokasi penelitian yaitu $5,35 \%$.

Kejenuhan basa merupakan perbandingan dari jumlah kation basa yang ditukarkan dengan kapasitas tukar kation yang dinyatakan dalam persen. Kejenuhan basa rendah berarti tanah memiliki kemasaman tinggi dan kejenuhan basa mendekati $100 \%$ tanah bersifat alkalis. Pada Ultisol nilai KB dari horizon Ap 139,8\%, horizon AB 4,35\%, horizon BA 99,3\%, horizon Bt1 122,8\%, dan horizon Bt2 14,01\%. Dan nilai KB jumlah kation pada tanah Ultisol yaitu dengan nilai $3,35 \mathrm{cmol}^{-1} \mathrm{~kg}$.

\section{Genesis Tanah dan Karakteristik Mineral Tanah}

Tabel 3. Hasil analisis karakteristik mineral tanah

\begin{tabular}{llll}
\hline No. & Jenis tanah & Jenis mineral & Peak $(\AA)$ \\
\hline 1. & Ultisol & Bayerit & $(4,71221)$ \\
& & Paligorskit & $(4,25369)$ \\
& Felsdpar & $(3,0024)$ \\
& Goetit & $(3,36580)$ \\
& Kuarsa & $(3,34161)$ \\
\hline
\end{tabular}


Tanah Ultisol terdapat bebarapa jenis mineral seperti paligorskit, goetit, felsdpar dan kuarsa tetapi didominasi oleh bayerit dengan nilai peak 4,71221 A. dari beberapa jumlah mineral yang terkandung lokasi penelitian ini didominasi oleh mineral mudah lapuk sehingga mudah terjadi pencucian. Bahan induk merupakan salah satu faktor pembentukan tanah, yang mempunyai peran dan pengaruh sangat penting dalam proses pembentukan dan perkembangan tanah. Oleh karena itu sifat-sifat bahan induk akan menurun pada sifat tanah baik itu sifat fisika, kimia, maupun sifat mineral tanah.

Tabel 4. Proses genesis yang dominan terjadi pada jenis Ultisol

\begin{tabular}{|c|c|}
\hline Proses genesis & Data pendukung \\
\hline \multicolumn{2}{|l|}{ Horizon Ap } \\
\hline -Dekomposisi (penghancuran) bahan organik & BO horizon Ap paling tinggi $1,8 \%$ \\
\hline \multicolumn{2}{|l|}{ Horizon AB } \\
\hline -Braunifikasi (pembentukan tanah berwarna cokelat) & hue $10 \mathrm{YR}$, value $=5$, kroma $=6$ \\
\hline \multicolumn{2}{|l|}{ Horizon BA } \\
\hline -Eluviasi (pencucian liat/debu halus maupun bahan lainnya) & $\begin{array}{l}\text { Kandungan liat horizon atas } 5 \% \\
\text { horizon dibawah nya } 23 \% \text { dan } 29 \%\end{array}$ \\
\hline \multicolumn{2}{|l|}{ Horizon Bt1 dan Bt2 } \\
\hline -Illuviasi (penimbunan liat/debu halus maupun bahan lain) & $\begin{array}{l}\text { Kandungan liat lebih besar dari horizon } \\
\text { di atas nya } 23 \% \text { dan } 29 \%\end{array}$ \\
\hline \multicolumn{2}{|l|}{ Horizon Bt1 } \\
\hline -Hardening (pengurangan pori akibat pemadatan) & bobot isi paling tinggi $1,55 \mathrm{~g} \mathrm{~cm}^{-3}$ \\
\hline
\end{tabular}

Keterangan: $\sqrt{ }=$ terjadi proses genesis, $-\sqrt{ }=$ proses genesis kurang nyata

Bahan induk tanah Ultisol yaitu Tuktp (Tertary III Tertary III upper keutapang). Jenis batuan yang terdapat yaitu batu sedimen, batu pasir, batu gampingan, batu lanau dan batu gamping kurang, terbentuk pada zaman Kenozoikum periode pertengahan meiosen-pliosen yang berumur antara 23,030 - 5,332 juta tahun yang lalu. Oleh sebab itu maka tanah Ultisol tergolong tua dan sudah mengalami perkembangan lanjut yang ditandai dengan solum tanah yang sudah dalam. Batu lanau banyak mengandung liat dikarenakan ukuran batu lanau sangat halus terbentuk dari pecahan kuarsa yang berukuran pasir dan kemudian terjadi pelapukan sehingga menjadi debu atau sering juga disebut batu debu. Sedangkan batu pasir dan batu gampingan terdapat beberapa jenis mineral campuran tetapi didominasi oleh bayerit dengan peak nya yaitu $4,71221 \AA$.

Dikarenakan didominasi oleh mineral mudah lapuk maka mudah terjadi pencucian karena didukung juga oleh keadaan iklim di lokasi penelitian sedang, juga memiliki panas dan dingin yang seimbang sehingga proses pelapukan terjadi lebih lanjut. Meskipun pada lokasi penelitian bertopografi landai tetapi juga terjadi pencucian yang di tandai adanya horizon iluviasi dan eluviasi. Vegetasi pada lokasi penelitian ini yaitu lahan pertanian lahan kering berarti kebun yang banyak terdapat tanaman perdu dan pepohonan yang tidak terlalu tinggi sehingga banyak menyumbangkan bahan organik yang ditandai dengan banyaknya kandungan bahan organik pada horizon Ap yaitu 1,89\%.

Proses genesis yang terjadi pada jenis tanah Ultisol di horizon Ap yaitu dekomposisi bahan organik lanjut ditandai dengan kandungan bahan organik yang tinggi di horizon Ap dibandingkan dengan horizon lainnya 1,89\%. Selanjutnya pada horizon AB yaitu proses braunifikasi tanah menjadi warna cokelat kekuningan dikarenakan adanya kandungan Fe yang dapat mempengaruhi warna matriks tanah $10 \mathrm{YR} 5 / 6$. pada horizon BA proses genesis yang terjadi eluviasi liat halus dan kandungan Fe kehorizon di bawahnya, ditandai dengan sangat 
sedikitnya kandungan liat pada horizon BA yaitu hanya 5\% dan Fe yang terkandung dihorizon ini tergolong sedang. Pada Bt1 dan Bt2 terjadi iluviasi yaitu penimbunan liat dan kandungan Fe yang ditandai dengan bertambahnya kandungan liat pada horizon ini yaitu $23 \%$ dan $29 \%$ dan Fe tergolong banyak.

\section{Klasifikasi Jenis Tanah}

Sistem klasifikasi yang digunakan dalam penelitian ini merupakan Soil Taxonomy (Soil Survey Staff, 2014). Berikut ini akan disajikan beberapa karakteristik klasifikasi tanah yaitu epipedon penciri tanah, horizon penciri bawah dan unsur-unsur pembeda tanah serta klasifikasi tanah dilokasi penelitian.

Tanah Ultisol tidak termasuk epipedon antropik karena tidak memiliki horizon permukaan yang tebal dan tidak memiliki ciri-ciri lainnya yang seprti epipedon molik, serta tidak mengandung $\geq 1500 \mathrm{mg} / \mathrm{kg} \mathrm{P}_{2} \mathrm{O}_{5}(220,8 \mathrm{mg} / \mathrm{kg})$. Tidak termasuk epipedon folistik karena tidak memiliki bahan organik setebal $\geq 20 \mathrm{~cm}$ (bahan organik/BO kasar) atau $\geq 15 \mathrm{~cm}$ (bahan organik sedang/halus). Tidak termasuk epipedon histik karena tidak memiliki lapisan yang dicirikan oleh adanya saturasi (selama 30 hari atau lebih, kumulatif) dan reduksi selama sebagian waktu dalam tahun-tahun normal. Tidak termasuk epipedon melanik karena tidak memiliki horizon permukaan dengan tebal $\geq 30 \mathrm{~cm}(10 \mathrm{~cm})$, dan tidak mempunyai sifat tanah andik. Tidak termasuk epipedon molik kecuali KB lebih besar dari 50\%. Tetapi termasuk epipedon okhrik karena horison permukaan tipis yaitu $10 \mathrm{~cm}$, walaupun kandungan bahan organik adalah 1,89\%, warna tanah dengan nilai value dalam keadaan lembab sebesar 5, sedangkan nilai chroma dalam keadaan lembab sebesar 6.

Endopedon tanah Ultisol tidak termasuk horison agrik karena tidak terdapat langsung di bawah lapisan olah yang mengandung akumulasi debu, liat dan humus. Tidak termasuk horison albik karena horizon berwarna pucat atau ada horison E. Tidak termasuk horison anhidrit karena tidak mempunyai lapisan anhidrit. Tidak termasuk horizon kalsik karena tidak mengandung $15 \% \mathrm{CaCO}_{3}(\mathrm{Ca}$ dd 4,00\%) sangat rendah. Tidak termasuk horison kambik karena ketebalan horison lebih dari $15 \mathrm{~cm}$ yaitu $18 \mathrm{~cm}$. Tetapi termasuk horizon penciri argilik karena memiliki horizon iluviasi apabila liat $15-40 \%$, maka harus mengandung liat 1,2 kali lebih banyak dari horizon eluviasi. Kandungan liat eluviasi pada lokasi penelitian yaitu 11\% dan horizon liat horizon iluviasi sebesar 23 dan 29\%. Horizon argilik memiliki kandungan liat lebih tinggi dari pada horizon di atasnya.

Salah satu sifat horizon argilik jika terdapat horizon selain Ap, mempunyai perbedaan tekstur antara horizon eluviasi dan horizon illuviasi dan batas horizon umumnya jelas atau sangat jelas. Horizon iluviasi umumnya memiliki tekstur lebih halus, berbeda dengan horizon eluviasi atau bahan induk dibawah nya. Nisbah kadar liat pada horizon iluviasi terhadap horizon eluviasi paling sedikit 1,2 kali lebih tinggi dari horizon eluviasi. Peningkatan 20\% tersebut terjadi pada kebanyakan pedon dengan jarak vertikal $<15 \mathrm{~cm}$. Batas bawah horizon argilik biasanya berangsur atau tidak teratur (Rachmin dan Arifin, 2011).

Kategori ordo di Desa Jantho/ Jalin tidak Tidak dijumpai horizon argilik dengan KB $\mathrm{pH}$ $8,2 \geq 35 \%$ pada kedalaman $1,8 \mathrm{~m}$ maka tidak termasuk Alfisol. Tidak mempunyai lapisan dengan sifat andik $\geq 60 \%$ pada kedalaman $<60 \mathrm{~cm}$ maka tidak termasuk Andisol. Tidak mempunyai epipedon antropik, dan tidak dijumpai horizon penciri bawah argilik atau natrik maka tidak termasuk Aridisol. Tidak termasuk Entisol karena tidak di jumpai sangat jenuh air (positif water potensial) pada permukaan tanah selama lebih dari 21 jam setiap pada seluruh tahun dan tidak memenuhi kriteria Entisol lainnya. tidak dijumpai bahan gelik pada kedalaman $\leq 100 \mathrm{~cm}$ dan permafrost pada kedalaman $\leq 200 \mathrm{~cm}$ maka tidak termasuk Gelisol. 
Tidak memiliki kandungan bahan organik $\geq 20 \%$, dan pada ketebalan $\geq 40 \mathrm{~cm}$ bahan tanah organik tidak terdiri dari bahan saprik atau hemik atau dari bahan fibrik yang serat lumutnya $<3 / 4$ volume maka tidak termasuk Histosol. Tidak mempunyai horizon salik atau epipedon histik, molik, plagen, atau umbrik, atau horizon kambik maka tidak termasuk Inceptisol. Tidak dijumpai epipedon molik dan KB pH 7 pada seluruh bagian solum tanah $\geq 50 \%$ maka tidak termasuk Mollisol. Tidak dijumpai horizon spodik dan plakik maka tidak termasuk Spodosol. Tidak mempunyi horizon penciri bawah oksik pada horizon $\mathrm{Bo}_{2}$ dengan tebal lapisan tanah $\geq 30 \mathrm{~cm}$ yaitu $\pm 35 \mathrm{~cm}$ maka tidak termasuk Oxisol. Tetapi termasuk kedalam Ultisol karena mempunyai horizon argilik yang bersifat masam dengan kejenuhan basa rendah dan KB jumlah kation kurang dari 35\% pada kedalam $<130 \mathrm{~cm}$.

Menurut Prasetyo dan Suriadikarta (2006) persyaratan klasifikasi Ultisol hanya didasarkan pada nilai kejenuhan basa yaitu $<35 \%$ dan adanya horizon argilik tanpa ada syarat tambahan horizon lainya. Ultisol dicirikan oleh adanya akumulasi liat pada horizon bawah permukaan sehingga menurunkan daya resap air dan meningkatkan aliran permukaan dan erosi tanah.

Kategori tingkat subordo Aquult yaitu Ultisol dengan rejim kelembaban tanah akuik konsentrasi redoks yang nyata pada kedalaman $>10 \mathrm{~cm}$ ditandai dengan banyak karatan $\mathrm{Fe}$ dan pada horizon argilik memiliki chroma 1. Kategori great group tidak termasuk Plinthaquult karena tidak mengandung plintik pada satu horizon atau lebih dalam $150 \mathrm{~cm}$ dari permukaan tanah mineral. Tidak termasuk Fragiaquult karena tidak mempunyai fragipan yang batas atasnya di dalam $100 \mathrm{~cm}$ dari permukaan tanah mineral. Tidak termasuk Albaquult karena tidak mempunyai perubahan tekstur nyata diantara epipedon okhrik atau horizon albik dan horizon argilik atau kandik yang memiliki daya hantar hidrolik keadaan jenuh pada horizon argilik atau kandik sebesar $0,4 \mathrm{~cm} / \mathrm{jam}$ atau lebih lambat. Tetapi termasuk Kandiaquult karena mempunyai salah satu kriteria horizon kandik yaitu KTK efektif < dari pada lokasi penelitian KTK efektif adalah 5,64 $\mathrm{cmol} . \mathrm{kg}^{1}$, dan kandungan liat tidak menurun $20 \%$ dengan bertambahnya kedalaman tanah.

Tingkat subgrup tidak termasuk Acraquoxic Kandiaquult karena tidak memiliki KTK efektif $\mathrm{pH} 7$, dan $\mathrm{Al}^{3+}$ sebesar $1,5 \mathrm{cmol} / \mathrm{kg}^{-1}$ liat atau kurang pada satu horizon atau lebih di dalam $150 \mathrm{~cm}$ dari permukaan tanah mineral. Tidak termasuk Arenic Plinthic Kandiaquult karena tidak mempunyai plintik 5 persen atau lebih berdasarkan volume pada satu horizon atau lebih di dalam $150 \mathrm{~cm}$ dari permukaan tanah mineral dan tidak termasuk ciri lainnya. Tidak termasuk Arenic Umbric Kandiaquult karena tidak mempunyai kelas tekstur (fraksi tanah halus) pasir kasar, pasir, pasir halus, pasir halus berlempung pada keseluruhan lapisan dari permukaan tanah mineral sampai batas atas horizon kandik yang berada pada kedalaman $50 \mathrm{~cm}$ sampai $100 \mathrm{~cm}$ dan mempunyai epipedon molik dan umbrik. Tidak termasuk Arenic Kandiaquult karena tidak memenuhi kriteria karena tidak mempunyai kelas tekstur (fraksi tanah halus) pasir kasar, pasir, pasir halus, pasir halus berlempung pada keseluruhan lapisan dari permukaan tanah mineral sampai batas atas horizon kandik yang berada pada kedalaman $50 \mathrm{~cm}$ sampai $100 \mathrm{~cm}$. Tidak termasuk Grossarenic Kandiaquult karena memenuhi kriteria karena tidak mempunyai kelas tekstur (fraksi tanah halus) pasir kasar, pasir, pasir halus, pasir halus berlempung pada keseluruhan lapisan dari permukaan tanah mineral sampai batas atas horizon kandik yang berada pada kedalaman $100 \mathrm{~cm}$ atau lebih. Tidak termasuk Plinthic Kandiaquult karena tidak mempunyai plintik 5\% atau lebih pada satu horizon atau lebih di dalam $150 \mathrm{~cm}$ dari permukaan tanah mineral. Tidak termasuk Aeric Kandiaquult karena tidak mempunyai 50\% atau lebih matriknya berkroma 3 atau lebih pada satu horizon A atau Ap kedalaman $25 \mathrm{~cm}$ dari permukaan tanah mineral dan kedalaman $75 \mathrm{~cm}$ mana saja yang lebih 
dalam. Tidak termasuk Umbrik Kandiaquult karena tidak mempunyai epipedon molik dan umbrik. Tetapi memenuhi kriteria Typic Kandiaquult karena tidak memenuhi syarat Kandiaquult lainnya. Famili Typic Kandiaquult, bedebu halus, campuran isohipertermik. Kelas ukuran besar butir bedebu halus, kelas mineralogi campuran dapat dilihat pada Tabel 10, dan kelas rejim temperatur tanah adalah isohipertermik yaitu suhu rata-rata tahunan $>22$ ${ }^{\circ} \mathrm{C}$ serta perbedaan suhu tanah rata-rata musim panas dan musim $>6{ }^{\circ} \mathrm{C}$.

\section{KESIMPULAN DAN SARAN}

Ultisol di Desa Jalin Jantho terbentuk diatas batuan Tuktp (Tertary III Tertary III upper keutapang). Jenis batuan yang terdapat yaitu batu sedimen, batu pasir, batu gampingan, batu lanau dan batu gamping kurang, terbentuk pada zaman Kenozoikum periode pertengahan meiosen-pliosen yang berumur antara 23,030 - 5,332 juta tahun yang lalu. Proses-proses genesis yang terjadi pada tanah Ultisol yaitu dekomposisi, braunifikasi, eluviasi, iluviasi dan hardening.

Termasuk dalam epipedon okhrik dan endopedon argilik, tingkat ordo termasuk dalam Ultisol, kategori subordo Aquult, kategori great group Kandiaquult, kategori subgrup Typic Kandiaquult. Tingkat famili Typic Kandiaquult, berdebu halus, campuran, isohipertermik.

Saran dari penelitian ini yaitu perlu dilakukan penelitian lanjutan pada titik yang berbeda mengingat lokasi pada penelitian ini hanya dilakukan di satu titik sampel saja di Kabupaten Aceh Besar.

\section{DAFTAR PUSTAKA}

Buol, S.W., F.D. Hole, and R.J. McCracken. 1997. Soil Genesis and Classification. 4 ed. Lowa State University Press.

Dudal, R and Soepraptoharjo. 1957. Soil Classification in Indonesia. Soil Research Institute. Bogor. 148 hal.

Hakim, N., Nyakpa, M.Y. Lubis, A.M. Nugroho, S.G. Diha, M.A. Hong, dan G.B. Bailey. 1986. Dasar-Dasar Ilmu Tanah. Universitas Lampung. 488 hal.

Hanafiah, K. A. 2005. Dasar-dasar Ilmu Tanah. Rajagrafindo Persada: Jakarta.

Handayani, S. dan H. S. Bambang. 2002. Kajian struktur tanah lapisan olah. Jurnal Ilmu Tanah dan Lingkungan. 33: 10 - 17.

Hardjowigeno, S. 2003. Klasifikasi Tanah dan Pedogenesis. Edisi kedua. Akademik Pressindo: Jakarta.

Hardjowigeno, S. 2010. Ilmu Tanah. Penerbit Akademika. Pressindo: Jakarta.

Martunis, L. Sufardi, dan Muyasir. 2016. Analisis indeks kualiatas tanah di lahan kering Aceh soilBesar. Jurnal Budidaya Pertanian. 12 (1): 34-40 Th. 2016 ISSN: 1858-4322.

Prasetyo, B.H. dan D.A. Suriadikarta. 2006. Karakteristik, potensi, dan teknologi pengolahan tanah ultisol untuk pengembangan pertanian lahan kering di Indonesia. Jurnal Litbang Pertanian 25(2):39-46.

Pusat Penelitian Tanah. 2009. Analisis Kimia Tanah, Tanaman, Air, Dan Pupuk. Bogor: Pusat Penelitian dan Tanah Agroklimat. Deptan.

Rachmin, D dan Arifin. 2011. M. Dasar-Dasar Klasifikasi Taksonomi Tanah. Pustaka Reka Cipta. Bandung. 402 hal. 
Soil Survey Staff. 2014. Kunci Taksonomi Tanah. Edisi Kedua Belas, Edisi Ketiga Bahasa Indonesia, 2015. Balai Besar Penelitian dan Perkembangan Sumberdaya Lahan Pertanian Badan Penelitian dan Perkembangan Pertanian Kementrian pertanian.

Sufardi, Darusman, Zaitun, S. Zakaria, and T.F, Karmil. 2017. Chemical characteristic and status of soil fertility on some dryland areas of Aceh Besar District (Indonesia). Proceeding of Internasional Conference on Suntainable Agriculture. Yogyakarta 17-18, 2017. 